\title{
Um Diálogo Inesperado: a social-democracia na teoria da democracia de Joseph Schumpeter ${ }^{2}$.
}

Poucos autores influenciaram de maneira tão inequívoca a teoria democrática na segunda metade do século XX como o economista e cientista social austro-americano Joseph Schumpeter. A concepção de democracia desenvolvida por ele em Capitalismo, Socialismo e Democracia (Schumpeter, 1984) foi fundamental para a construção de agendas de pesquisa na ciência política norte-americana (Ricci, 1970), assim como auxiliou a definir o terreno analítico que setores importantes da ciência política deveriam assentar as bases interpretativas acerca das instituições políticas democráticas - e não democráticas (Huntington, 1994). Pode-se dizer que Schumpeter é o autor principal do que na literatura especializada se chama de teoria elitista da democracia. Para alguns pesquisadores ele teorizou a defesa da democracia domesticada (Miguel, 2002). Lê-se Schumpeter, portanto, como o teórico que restringiu a democracia a apenas um método (arranjo) organizacional de seleção de elites políticas que competem entre si pelo voto do povo através da disputa eleitoral. É o que se chama conceitualmente na ciência política de concepção procedimental e/ou minimalista da democracia (Gama Neto, 2011). Mais do que consolidada, essa leitura da teoria democrática do economista e cientista social austríaco é praticamente

Universidade de São Paulo, São Paulo, SP, Brasil. E-mail: <ronaldolais@yahoo.com.br>.

2 Este artigo é uma versão alterada do capítulo 4 de minha dissertação de mestrado defendida no Programa de Pós-Graduação em Ciências Sociais (Área Política) da PUC-SP. Agradeço ao meu orientador, Cláudio Gonçalves Couto e aos membros da banca, Miguel Chaia e Adrian Gurza Lavalle, a este em especial, por incentivar para que publicasse partes de minha pesquisa de mestrado. 
a única explicitada nos debates contemporâneos sobre seu legado para a problematização da democracia e suas possibilidades. Isto ocorre porque a abordagem convencional lê e estuda Capitalismo, Socialismo e Democracia focando sua argumentação apenas na Parte $I V$, Socialismo e democracia; em especial nesta parte está o capítulo 22 (Outra teoria da Democracia), na qual encontramos o núcleo da democracia elitista-procedimental, a saber; democracia se converte agora " $[\mathrm{n}]$ o método democrático, [o] acordo institucional para se chegar a decisões políticas em que [...] indivíduos adquirem o poder de decisão através de uma luta competitiva pelos votos da população" (Schumpeter, 1984, p. 336). Sem nenhuma pretensão em afirmar que essa leitura convencional está equivocada, ou mesmo superada por pesquisas recentes, o presente artigo objetiva tratar a teoria democrática de Schumpeter a partir de outro ângulo. Minha hipótese de trabalho é que o economista e cientista social austríaco estava interessado nas condições de operatividade do método democrático, mais do que em sua construção, definição e delineamento em si, e que esta operatividade pressupunha, nos termos de Schumpeter, abordar então a questão política e histórica dos partidos socialistas, mais precisamente do movimento social-democrata europeu.

$\mathrm{O}$ artigo está organizado da seguinte maneira: primeiro, procura-se evidenciar que Capitalismo, Socialismo e Democracia, doravante C.S.D., resultou das leituras, estudos e debates de Schumpeter com o movimento socialista (social-democrata), e não em uma crítica à doutrina clássica da democracia e à construção do método institucional de seleção de governantes, ainda que estas questões sejam parte da estrutura fundamental da teoria democrática de nosso autor; segundo, analisaremos dois capítulos da desconhecida Parte II - Poderá Sobreviver o Capitalismo (são eles, Paredes em Desmoronamento e Hostilidade Crescente) de C.S.D., capítulos esses de grande importância para a estrutura argumentativa que Schumpeter irá desenvolver na Parte IV-Socialismo e Democracia, embora a articulação mais formal entre essa parte e os capítulos referidos não tenha sido elaborada com precisão pelo autor; terceiro, apresentaremos um breve percurso sobre o movimento social-democrata 
objetivando melhor compreender os parâmetros histórico-políticos em que Schumpeter se baseou para erigir seu modelo teórico; e quarto, discutiremos as condições de operatividade do método democrático-procedimental de seleção de lideranças tendo o movimento social-democrata uma agência imprescindível para isso, neste ponto nosso estudo estará focado no capítulo 23 de C.S.D., $A$ Inferência.

\section{Joseph Schumpeter e o Socialismo ${ }^{3}$}

A teoria democrática de Joseph Schumpeter é apreendida pelos especialistas na ciência política de três maneiras básicas: como concepção elitista da política, como visão procedimental e institucional da democracia e como leitura econômica da mesma. Poucos estudiosos de Schumpeter e sua concepção de democracia analisam suas proposições teóricas e políticas como um diálogo travado por ele com certos setores do movimento socialista. Em parte essa lacuna na literatura, sobretudo na literatura sobre teoria democrática, se deve ao próprio modo como Schumpeter desenvolveu sua argumentação na Parte IV de C.S.D. A teoria schumpeteriana da democracia começa com uma contundente crítica à doutrina marxista, passa pela crítica à noção clássica de democracia e pela participação efetiva e direta do povo na política (nas decisões de governo) e finda com a construção do arranjo ou método para selecionar a elite governante que compete exclusivamente entre si pela preferência eleitoral do homem comum. Se o leitor de C.S.D. não ultrapassar as formulações inequívocas do texto e não retornar ao início da obra, de sorte a compreender sua arquitetura teórica e a estrutura de argumentação enquanto tal, as possibilidades de entendimento da teoria elitista da democracia de Schumpeter como um diálogo com a social-democracia ficarão comprometidas. Isso significa dizer que se perde a oportunidade de se abordar com maior

3 Mesmo Schumpeter utilizando longo de Capitalismo, Socialismo e Democracia partido socialista, ou socialismo, no presente artigo, como se verá mais à frente, preferi me valer, na maioria das vezes de movimento ou partido social-democrata. Pois tanto está mais em consonância com minha hipótese de trabalho, como a própria argumentação e exposição de Schumpeter em referida obra está mais próxima dessa corrente no interior do socialismo. 
profundidade o estatuto da teoria democrática desenvolvida pelo economista austríaco, bem como suas implicações para a política prática e democrática contemporânea. No entanto, quais as evidências que sustentam nossa assertiva? Por que é possível sustentar que a concepção (elitista) de democracia de Schumpeter pressupõe a agência social-democrata enquanto condição de operatividade do método institucional de seleção de governantes?

Três circunstâncias podem ser apresentadas para sustentar nossa argumentação de que a teoria democrática de Joseph Schumpeter foi construída em diálogo com a social-democracia europeia - alemã e austríaca, principalmente. A primeira circunstância repousa na própria intenção e objetivo de C.S.D.; a segunda circunstância refere-se ao contexto de formação intelectual, teórica e política de Schumpeter e; a terceira circunstância deve-se ao percurso biográfico-político do autor de C.S.D. Vejamos um pouco mais em detalhe estas três circunstâncias.

No prefácio à primeira edição de C.S.D., Schumpeter explicita o que seu trabalho significava em termos de projeto pessoal e intelectual. Para ele C.S.D. era a conclusão de diversos estudos, reflexões, pensamentos e teorizações sobre o movimento socialista. Diz ele, então, que seu livro "constitui uma tentativa de fundir, em forma coerente, quase quarenta anos de pensamentos, observações e pesquisas sobre o socialismo" (1961, p. 3). Note-se que Schumpeter não menciona no prefácio que seu livro objetivava a construção de um método institucional de seleção de governantes, e ele também não apresenta C.S.D. como a apropriação da ciência econômica com o intuito de fornecer uma teoria democrática realista. No que concerne particularmente à democracia, ou ao método democrático, sua problematização, de acordo com Schumpeter, teve necessariamente de ser feita no lugar específico em que "ocupa [no] volume" (1961, p. 3), a Parte IV - Socialismo e Democracia. A observação que Schumpeter nos oferece no primeiro prefácio à sua obra mais conhecida passou (e ainda passa) despercebida para muitos leitores e intérpretes de sua teoria democrática. Com efeito, foi a partir do diálogo (de toda uma vida) com o movimento socialista 
que o economista erigiu uma das principais e mais influentes concepções de democracia da segunda metade do século XX. Os motivos, peculiarmente teóricos, políticos e históricos que levaram Schumpeter a empreender tal diálogo, serão demonstrados mais à frente. Neste ponto ainda, a segunda circunstância adquire prioridade em nossa argumentação. No contexto da belle époque vienense a vida intelectual, cultural, estética e artística floresceu a tal ponto, que alguns autores chegaram ao deslumbramento de compará-la com a "Atenas no tempo de Péricles [e/ou com a] Florença sob Lorenço o Magnífico" (Marz, 1991 p. 99). E esta mesma Viena ${ }^{4}$, também, propiciou um ambiente social e político fértil para a "teoria econômica" (Ibidem). Foi dessa forma que Schumpeter presenciou (e participou) do debate entre a escola econômica da utilidade marginal e a escola austro-marxista, representada pelos social-democratas Rudolf Hilferding, Karl Renner e Otto Bauer. Ainda que os economistas da escola da utilidade marginal, com nomes da envergadura de Carl Menger, Bohm-Bawerk, Von Wieser e Ludwig Von Mises, tivessem contribuído enormemente para as discussões econômicas na Áustria da belle époque, no contexto do entre guerras e com a crise do modelo econômico do livre mercado, os teóricos da social-democracia e o debate sobre a socialização ganharam maior projeção, superando, naquele momento, seus oponentes liberal-marginalistas (Ibidem, pp. 101 e 108). Assim, as primeiras reflexões do jovem Schumpeter sobre economia, teoria política e social apareceram no âmbito do debate, no período do entre guerras, entre as duas escolas austríacas de economia, os marginalistas-utlitários e os social-democratas -, de modo que o interesse, a concordância em certos pontos e a própria projeção e relativo prestígio fizeram Schumpeter incorporar em seu pensamento e preocupações as questões abordadas pelos últimos.

A terceira circunstância pela qual podemos argumentar que C.S.D. estava não só preocupado em erigir uma teoria democrática

4 Schumpeter também presenciou a experiência da Viena vermelha. O experimento socialista (ou social-democrata) para se administrar, especificamente, a cidade Viena. Ver sobre isso, Siegfried Mattl - O Caso da Viena Vermelha, Lua Nova, no 89. 
como método procedimental de seleção de governantes pode-se basear no próprio percurso biográfico de Joseph Schumpeter. Antes de se tornar o renomado professor de economia e ciências sociais na Universidade de Harvard nos Estados Unidos em meados do século $\mathrm{XX}$, ele teve um percurso singular em sua vida pessoal e intelectual. Nascido no fim do século XIX (1883) em uma família tradicional de Triesch, cidade situada na região da Moravia na Tchecoslováquia (Swedberg, 1991, pp. 6 e 7), Schumpeter esteve convencido dos valores conservadores, sobretudo, no âmbito dos costumes e da cultura. Seu projeto político para a Áustria no início do século XX era a manutenção da Monarquia com uma federação de Estados - todos independentes do Império Alemão (Allen, 1991, p. 161). Os eventos históricos e políticos que surgiram com o advento da I Guerra Mundial frustraram os anseios de Schumpeter. Ele, que já havia teorizado acerca das fragilidades econômicas, institucionais e organizacionais do capitalismo competitivo (de livre mercado), viu a Europa central enfrentar uma série de revoltas sociais (Marz, 1991, p. 101), o que ocasionou a mudança de status dos partidos social-democratas do continente. Nos países de língua germânica, especialmente, a social-democracia, muito em consequência do desprestígio das forças político-partidárias tradicionais e seus interesses econômicos pela guerra, chegaram ao poder, passando com isso a administrar os negócios estatais. Schumpeter, que naquele momento já era conhecido como um dos principais economistas da Europa por seus trabalhos sobre desenvolvimento econômico e evolução do capitalismo, foi convidado a participar da Comissão para Socialização na República Alemã e posteriormente, no governo socialista de Karl Renner na Áustria, será Ministro das Finanças (Scheuerman, 2001, pp. 242 e 243). Com efeito, a convivência do autor de C.S.D. com diversos socialistas, em particular, os social-democratas, tais como Hilferding, Emil Lederer, Kautski e Otto Bauer - este último que junto com ele havia sido "aluno de Bohm-Bawerk" (Johnston, 1972, p. 84) - foi intensa nas primeiras décadas do século XX. Isto não somente porque estes eram grandes teóricos da economia e da política, eram importantes intelectuais; mas porque estavam diante de uma experiência histórica 
e de grande magnitude para as sociedades europeias: a possibilidade de transição do capitalismo para o socialismo. Joseph Schumpeter retomará sua experiência política e intelectual com os sociais-democratas em C.S.D., porém aqui a experiência irá se transformar em modelo teórico e conceitual (Stolper, 1994, p. 210). Se das perspectivas da circunstância intencional e objetiva da obra, da circunstância de contexto histórico e da circunstância biográfica podemos inferir que a teoria democrática erigida por Schumpeter é resultado de seu diálogo e convivência com o movimento socialista, a social-democracia com maior destaque, quais são os motivos teóricos, por um lado, e histórico-políticos, por outro, que nos levam a argumentar que a social-democracia é fundamental e imprescindível na estruturação do método institucional de seleção de governantes no que concerne à operatividade estável desse? Devemos assim incursionar no conjunto de C.S.D. para entendermos os problemas que Schumpeter buscava resolução.

\section{O Fim da Armação Protetora da Sociedade Capitalista: como recuperá-la?}

Uma passagem de Wolfgang Stolper nos insere na argumentação deste ponto sobre a importância decisiva da social-democracia na construção operativa do método institucional-democrático de seleção de líderes. Diz ele:

Schumpeter argumenta [em] dois níveis diferentes. No nível da teoria econômica ele assevera que a maquinaria capitalista [...] funciona suficientemente bem de modo que não há razões puramente econômicas para esperar sua queda ou mesmo que ele ira exaurir todas as possibilidades de desenvolvimento [...] [Schumpeter] acredita que ideias de estagnação secular [sejam] absurdas. [Mas] há também o nível sociológicopolítico-institucional. O pessimismo de Schumpeter sobre o futuro do capitalismo é baseado em tendências que ele vê e analisa neste nível [...] [Aqui a] teoria [compreende e] anali[sa] como instituições [...] firmas, governo, método [político] de 
encontrar e adaptar-se a novas coisas - mudam sua própria lógica. A extensão do argumento do puramente econômico pra o sociológico-político-institucional [...] é a lógica consequente da análise do desenvolvimento da economia em si mesma que necessariamente produz constantes mudanças institucionais (Stolper, 1994, p. 108).

Joseph Schumpeter, portanto, entendia o processo de desenvolvimento capitalista através de articulações assimétricas entre o nível econômico e o nível sociológico-político-institucional. A assimetria resulta que, ao passar dos anos, o nível sociológico-político-institucional foi adquirindo maior projeção no conjunto da teorização acerca das tendências e perspectivas da evolução do capitalismo (Ibidem). Assim, a partir dessa evolução o programa de investigação de Schumpeter tinha três objetivos a serem alcançados: 1) a superação da dicotomia metodológica que havia no Methodenstreit ${ }^{5}$ germânico a respeito de se os fundamentos da análise econômica deveriam basear-se na teoria econômica ou em circunstâncias históricas e culturais das sociedades humanas (Ebner, 2000); 2) compreender qual a dinâmica do processo de evolução social a partir da necessidade de inovação constante da economia de mercado para a sobrevivência do capitalismo (Andersen, 2006; Witt, 2002); e 3) a verificação das condições de permanência da ordem política, social e cultural de sustentação da economia capitalista (Prisching, 1989). C.S.D., pode-se afirmar, é a peça teórica mais importante do programa de investigação da sociologia econômica

5 Methodenstreit traduz em inglês para battle of methods, batalha de métodos. Methodenstreit foi um debate suscitado entre teóricos econômicos na Alemanha e na Áustria acerca de como compreender o desenvolvimento econômico das sociedades humanas, sobretudo no contexto do capitalismo. Havia aqueles que defendiam que o método de investigação deveria ser baseado na evolução pura da economia e suas leis internas e aqueles que entendiam que o melhor modo de empreender tal investigação seria articulando elementos da cultura, da moral, dos hábitos e da política das respectivas sociedades humanas no entendimento de como se dá o desenvolvimento econômico. Entre os primeiros estão os economistas da utilidade marginal, Carl Menger, Leon Walras e Stanley Jevons; entre os segundos estão Max Weber e Gustav Schmoller e Joseph Schumpeter. Claramente aspectos fundamentais de Capitalismo, socialismo e democracia refletem os debates travados no Methodenstreit por Schumpeter. Sobre isto, ver Richard Swedberg -The New Battle of Methods, Challenge, n 33, v. 1, 1990. 
construída por Schumpeter. Lembremos aqui, novamente, que nossa hipótese de trabalho propõe defender que C.S.D. e a teoria democrática nele contida pressupõem a presença, inevitável, do movimento social-democrata, de modo a dar condições de operatividade institucional ao método democrático e/ou ao procedimento para a seleção de líderes através da luta competitiva pelo voto do povo. Na sociologia econômica específica de C.S.D. nosso autor narra, com erudição enciclopédica típica do mandarinato alemão e austríaco, o amplo movimento histórico e político que conduz ao posicionamento peculiar da social-democracia em sua teoria elitista da democracia. O núcleo constitutivo da narrativa schumpeteriana é o processo de degeneração e dissolução da economia capitalista por motivos exógenos ao sistema. A própria arquitetura da exposição do economista austríaco revela suas preocupações e problemas para que busca solução; pois o livro começa, após as suas imprescindíveis justificativas nos prefácios que comentamos há pouco acerca do caráter e intenção da obra, com uma análise da doutrina de Marx em suas diversas dimensões (o Profeta, o Sociólogo, o Economista e o Professor), em que o filósofo alemão surge tanto como teórico do socialismo religioso, como o pensador consciencioso de sua época - como teórico que assenta suas abordagens no melhor do pensamento científico de seu tempo (Schumpeter, 1961, pp. 11 e 12). A análise avança para dois conjuntos de investigações coordenadas pelas perguntas retórico-heurísticas: Poderá sobreviver o capitalismo? (Parte II) Será viável o socialismo? (Parte III). Naturalmente, Schumpeter, após abordar as várias dimensões da doutrina marxista, passa para o entendimento daquilo que foi o centro investigativo de toda a teoria econômica e política socialista: o estudo do capitalismo, suas formas políticas e as circunstâncias pelas quais seria possível a transição para o socialismo, bem como que tipo de socialismo seria. O Magnum Opus de Schumpeter termina, efetivamente, na famosa Parte IV - Socialismo e Democracia, parte essa em que se encontra a teoria democrática desenvolvida e acabada por ele. Do ponto de vista substantivo meu argumento concentra sua análise em dois capítulos da Parte II - Poderá Sobreviver o 
capitalismo? Não são escolhas arbitrárias. Os dois capítulos, que possuem os títulos Paredes em Desmoronamento e Hostilidade Crescente, são abordagens interpretativas essenciais para o conjunto da teoria democrática do economista austríaco. Perceba-se que os dois capítulos estão localizados no final da Parte II a que nos referimos, após Schumpeter explicitar toda a mecânica de funcionamentos da economia capitalista e suas debilidades. E antes dele apresentar a viabilidade do socialismo e a parte em que se encontra a teorização do método institucional de seleção de governantes pelo voto do povo. O que contêm os referidos capítulos? Vejamos.

Uma das teses fortes da sociologia econômica de Joseph Schumpeter é a de que o capitalismo tenderia à decomposição no curso de sua evolução histórica (Scheuermann, 1999; Swedberg, 1991). À narrativa de que o capitalismo tenderia à decomposição ao longo do tempo, o que poderia conduzir ao socialismo, Joseph Schumpeter agrega uma análise na qual apresenta o quadro institucional e político da decadência da economia de mercado. No entanto, ele empreende uma análise heterodoxa: Schumpeter não analisa os pontos que caracterizariam o quadro institucional e político da própria sociedade burguesa, mas sim a evolução do sistema feudal e sua função no âmbito da passagem desse quadro institucional enquanto tal para o quadro político-institucional moderno. Com efeito, a ascensão do agente econômico burguês aos lugares estruturais mais significativos de organização da política e da administração da sociedade havia produzido alterações sensíveis no ordenamento social, de tal modo que a realização dessa transformação ocasionaria duas situações: a primeira foi deslocar a forte influência do arranjo institucional feudal da vida econômica (e social); a segunda foi romper as barreiras feudais que limitavam o pleno desenvolvimento cultural e organizacional da economia burguesa. Assim, a dinâmica capitalista destruiu o sistema político do mundo feudal retirando as prerrogativas institucionais da nobreza latifundiária, do grupo clerical e dos homens gentis (Schumpeter, 1961, pp. 169 e 170). Entretanto, até que ponto, se pergunta Schumpeter, as cadeias e barreiras que o quadro institucional feudal representava para a 
evolução capitalista eram boas ou não para o agente econômico burguês como um todo? Pois, conforme o próprio Schumpeter avaliava: "as cadeias [e as barreiras] não apenas limitavam, mas também protegiam" (Grifo meu) (Ibidem). Observe-se quanto a isso que, na narrativa schumpeteriana concernente ao quadro político-institucional feudal e às alterações que ele sofre decorrente da ascensão do agente burguês, enfatiza-se que não há a completa destruição dos arranjos estruturais da organização política e social feudal. É que existe neste contexto um complexo processo de interação e de troca de funções entre os setores do mundo feudal e a classe capitalista ascendente. Procurando pelo "diagnóstico correto" do fenômeno que está narrando, o economista austríaco afirma que "o rei, a côrte, o exército, igreja e a burocracia viviam cada vez mais à custa das rendas capitalistas" (Ibidem, 171). Com isto, "o desenvolvimento da [economia] capitalista" passava a ser, indiretamente, fonte de recursos para os "elementos feudais" (Ibidem). Ora, o fenômeno que surge a partir dessa interação e intercâmbio entre os elementos feudais e o sistema capitalista é o de uma simbiose denominada por Schumpeter como: "armação de aço" (Ibidem). De outro ângulo, essa simbiose observada por Schumpeter, a armação de ação, só foi possível na medida em que a evolução histórica capitalista permitiu a sobrevivência relativa de setores do grupo feudal nos espaços político-institucionais mais importantes da nascente estrutura do Estado moderno. A ocorrência desse fenômeno, segundo a análise de nosso autor, se deve ao fato de a primeira forma que toma o Estado moderno, a Monarquia absoluta, possuir significativa influência e prestígio frente aos setores feudais; porém o caráter peculiar daqueles residia na concessão de cargos e pensões para os membros da nobreza, bem como para o clero. Isto fez com que (a nascente) máquina estatal moderna fosse administrada e conduzida por esses mesmos membros da nobreza e, em menor medida, por setores do clero. A consequência dessa dinâmica evolutiva foi uma simbiose ativa de dois agrupamentos sociais distintos, de modo que um organizava e administrava a economia (o agente burguês) e o outro organizava e administrava as estruturas institucionais da 
política - as repartições públicas, a estratégia nacional, os homens e os técnicos do exército. Estes se constituíram para Schumpeter em "classe dirigente" (Schumpeter, 1961, p. 171).

Havia ainda outro aspecto da simbiose narrada em C.S.D. Dois termos são mobilizados neste ponto específico: o de "vestígio da auréola mística" e a "auréola simbólica do prestígio". Assim, o fato de os agentes industriais e comerciais não possuírem nem a auréola mística nem o prestígio simbólico é que os tornava pouco afeitos a dirigir e comandar de maneira decisiva a política nacional. Lidar com diários de contabilidade e cálculos de custo, na análise de Schumpeter, não autorizava aos novos atores econômicos a se conformarem como líderes políticos de nenhum grande Estado nacional. Assim, o processo rotinizado de verificar e anotar os diários de contabilidade e a racionalidade na observação dos cálculos de custo não possuíam "qualquer vestígio de auréola mística” (Ibidem, p. 172). Inversamente ao agente burguês, os senhores medievais possuíam qualificações notáveis para proteger os seus interesses de grupo. Possuíam a "habilidade e [o] hábito de comandar e ser obedecido, envolvido num prestígio [místico]" (Ibidem) a classe medieval possuía os elementos fundamentais de todo exercício efetivo do poder político. E transformados em "administradores" (Ibidem) das instituições do Estado moderno nascente - "diplomatas, políticos e funcionários [...]" (Ibidem) -, os homens medievais não perderam sua capacidade de conduzir e o hábito do mando. Seu tradicional prestígio ainda permaneceu por longo tempo. Em vista disso, a capacidade de exercer o domínio e de conduzir homens é que diferenciava o líder feudal do líder capitalista e seu empreendimento industrial e racionalista. Gênio em seu escritório, dotado para as tarefas técnicas e rotineiras do cotidiano da administração como o cálculo de custo e o rendimento da produção, ele era incapaz de se defrontar com problemas que apresentassem níveis elevados de complexidade política. Para Schumpeter, os agentes econômicos burgueses não eram mesmo sequer capazes de "afugentar um rato, seja na sala de visitas seja na tribuna” (Schumpeter, 1961, p. 172). O 
que desejam, na verdade, era deixar essas questões importantes para sua própria sobrevivência "de lado" - ou para outros.

Dessa forma, foi uma vantagem quase que insubstituível para as pretensões do agente capitalista a permanência do grupo feudal nas estruturas organizativas do estado moderno decorrência da simbiose (ativa), que por sua vez formava a "armação de aço" do quadro institucional e político. Se o agente econômico burguês era incapaz de conduzir os negócios do Estado, inclusive quando estes eram de seu próprio interesse, era vantajoso então para ele deixar intacta a estrutura protetora que lhe forneciam os grupos feudais. Schumpeter, assim, chega à conclusão que sem a armação protetora do elemento "não-burguês", o agente econômico capitalista é "inerme" e sem habilidade política para comandar e liderar a nação (Ibidem, p. 174). E mais: ela é inábil para proteger e defender seus próprios interesses grupais; os agentes capitalistas, impreterivelmente, "necessita[m] de um senhor" (Ibidem). Entretanto, o trágico e angustiante, dadas as circunstâncias históricas, é que o próprio processo dinâmico da evolução do sistema capitalista, dada a sua mecânica de organização e funcionamento, assim como sua configuração sócio-psicológica, acabou separando e afastando os grupos protetores - a ação econômica e social dos agentes burgueses foi muito além do necessário na destruição da ordem institucional feudal e aristocrática. Ou seja: com a destruição pelo progresso capitalista da "simbiose [que] era elemento essencial para a sobrevivência do sistema” (Ibidem), o grupo burguês estava seriamente em perigo existencial. Com as paredes em desmoronamento o reinado do agente empresarial fica indefeso e passa a ser um convite à agressão, "especialmente se o botim é rico" (Ibidem, p. 179). Neste ponto a narrativa de Schumpeter passa a expor a hostilidade crescente ao capitalismo.

A formação da cultura hostil crescente ao capitalismo é consequência inevitável do esfacelamento da armação de aço que protegia o agente econômico burguês durante o período de sua existência. É que, na medida em que as paredes protetoras desmoronavam, a hostilidade se disseminava. Schumpeter afirma, portanto, que 
existiu "alta correlação [...] histórica [...] entre o desamparo capitalista e a hostilidade à ordem capitalista" (Schumpeter, 1961, p. 179). No entanto, a característica da hostilidade crescente ao capitalismo e à sociedade moderna na narrativa schumpeteriana possuía aspecto singular: não era a constatação por C.S.D. daquilo que Marx no Manifesto Comunista diagnosticava como luta de classes; mas a predisposição do grupo de intelectuais a fazer críticas cada vez mais radicais ao sistema econômico do livre mercado, da competição e da acumulação de lucro. Na avaliação de Schumpeter, ainda que os setores sociais mais prejudicados se insurgissem contra a ordem política e social do capital, eles não seriam suficientes para ensejar hostilidade política e cultural que perturbasse extraordinariamente o equilíbrio social e econômico do capitalismo. Dessa forma, a oportunidade histórica concreta com o advento dos grupos sociais prejudicados pela nova economia não provocaria a hostilidade ativa à ordem social e política vigente, pois havia a necessidade de grupos específicos que não só tivessem o interesse em estimular a crítica e o ódio, mas que conseguissem organizar, expressar e liderar o ressentimento crescente dos principais elementos grupais da nova ordem socioeconômica (Ibidem, p. 185). Neste capítulo da Parte II, Schumpeter formula uma argumentação que ele irá desenvolver na Parte IV - Socialismo e Democracia e que será fundamental em nossa problematização acerca da relação necessária concernente à operatividade do método institucional de seleção de governantes e social-democracia. A saber, de que "a massa jamais desenvolve opiniões definidas por iniciativa própria. [E] é ainda menos capaz de divulgá-las e transformá-las em atitudes e ações correntes" (Ibidem). O homem do povo, o cidadão comum, segue apenas "a liderança coletiva”. De modo que, para nosso autor, o grupo social específico com condições de empreender tal tarefa havia sido (e é): o grupo dos intelectuais. É a eles que cabe a função de estimular e organizar a revolta irracional contra a ordem econômica, política e cultura capitalista. Assim, para a melhor apreensão e resolução de seu problema teórico-político, Joseph Schumpeter foi obrigado a construir o que podemos chamar de sociologia dos intelectuais. 
Destaco aqui dois pontos nessa construção interpretativa apresentada pelo economista austríaco em C.S.D.: primeiro, a expansão da cultura crítica decorrente da ascensão do humanismo juntamente com o capitalismo; segundo, a formação na sociedade moderna da opinião pública e da liberdade de expressão.

No interior da Idade Média surgiram os primeiros traços da cultura intelectual e acadêmica crítica. Foi aí que germinaram as instituições universitárias europeias. Não é ocasional que neste período introduziu-se no ocidente o pensamento de Aristóteles por, entre outros pensadores, Thomas de Aquino. Entretanto, é com o humanismo que a atividade intelectual ganha corpo e significado político e cultural. Na Idade Média, ainda que lançando as bases para os séculos vindouros concernente ao que seria a vivência das discussões e debates universitários e acadêmicos, a função do intelectual era restrita, já que muitos eram considerados hereges (Ibidem, p. 184). No humanismo o trabalho intelectual foi amplamente disseminado e aceito. A motivação para isto havia sido o próprio caráter da formação dos primeiros intelectuais que surgiram no ocidente. Com conhecimento erudito, os primeiros grupos de intelectuais que apareceram no humanismo pautavam-se pela abordagem crítico-filológico dos textos e das escrituras. Assim, da crítica dos textos - políticos, filosóficos e religiosos - para a crítica da sociedade o caminho foi fácil e muito mais curto do que se poderia imaginar; era deste modo que o humanismo (que também estava sendo impulsionado pela nascente cultura capitalista que começava a propagandear: a liberdade do comércio, a necessidade de universalização das fronteiras europeias para a expansão dos negócios e as crescentes inovações no processo industrial) propiciou aos intelectuais a possibilidade de atitude crítica que, com o passar do tempo, "tornou-se cada vez mais forte" (Ibidem, p. 185). Para a completa formação do grupo de intelectuais hostis ao sistema capitalista e seus primeiros agentes econômicos e sociais, faltava outro elemento de não menor importância que a relação entre o humanismo e a crítica da sociedade - precisava-se da construção da opinião pública e da liberdade de expressão. Sempre impulsionado 
pela força irresistível do capitalismo, o processo de urbanização, vale dizer, o aumento do público citadino, era demandante da conformação de uma opinião que informasse e analisasse as novas circunstâncias históricas e políticas do moderno sistema econômico baseado na troca constante e ininterrupta de mercadorias.

A opinião pública e seus portadores, uma vez formados, necessitavam de instrumentos e meios de disseminação para atender as exigências dos citadinos. Assim, "o livro, o jornal e o panfleto" (Ibidem, p. 186) apareceram como mecanismo de divulgação da crítica intelectual à sociedade de então. Historicamente, Schumpeter argumenta que as condições de crítica pública e do surgimento dos instrumentos e meios de divulgação que a tornou possível "beneficiou-[se]", e mesmo deveu-se, "à [própria] ascendência da riqueza e da posição social da burguesa industrial" (Ibidem), de tal modo que o caráter incidental do significado político do grupo intelectual e da opinião pública beneficiava a ordem social e cultural capitalista em sua busca por legitimação, mas ao mesmo tempo conduziu ao proscênio social e político figuras como Voltaire. Na sociologia dos intelectuais de C.S.D., Voltaire é a figura típica do grupo intelectual crítico da sociedade moderna capitalista que surge dos escombros da Idade Média. O autor de Candido ou o otimismo "constituiu um exemplo inestimável" (Ibidem) do pensador hostil à ordem geral capitalista. Com curiosidade extremada combinando "superficialidade[s] que o torn[ava] capaz de abranger todos os campos, [...] uma vitalidade indomável e um instinto [crítico e irreverente] infalível [...] leviano" (Ibidem) Voltaire seduzia e arrebatava os ânimos descontentes. A situação narrada por Schumpeter torna-se mais difícil à medida que o grupo intelectual alcança mais independência, fica mais incontrolável e suas ações atingem níveis incontornáveis para a ordem política e social capitalista. Não foi mero acaso que a violenta irrupção da Revolução Francesa de 1789 tinha como personagens os principais "demagogos de tabloides (Marat, Desmoulin)" (Schumpeter, 1961, p. 187), advogados liberais radicais, que liam Rousseau e Montesquieu. A incapacidade de controlar o grupo intelectual se deve ao fato de que, para 
realizar isto, os agentes econômicos burgueses teriam que limitar, restringir e até mesmo acabar com a liberdade de expressão e, consequentemente, com a opinião pública ${ }^{6}$. Essa medida extrema, porém, significaria acabar com sua própria liberdade e capacidade de ação - assim, o novo agente econômico capitalista ficou de mãos atadas frente à crítica hostil dos intelectuais. Pois "a liberdade que desaprovava não poderia ser esmagada sem esmagar também a liberdade que defendia" (Ibidem, p. 188).

Se houvesse alguma esperança, mesmo que limitada, para a normalidade da ordem social burguesa para Schumpeter, ela residiria na seguinte circunstância: enquanto tal, a hostilidade e a crítica intelectual num primeiro momento tinham efeitos inofensivos. É que a "hostilidade do grupo intelectual, naturalmente (importando na condenação moral da ordem capitalista) é uma coisa, e outra muito diferente a atmosfera de geral hostilidade que cerca o sistema" (Ibidem, p. 191). Para Schumpeter é justamente, e do ponto de vista realista, este "últim[o] [...] fenômeno" o que realmente importa (Ibidem). Pois aquela segunda hostilidade "não [é] simplesmente o produto da primeira" (Ibidem). Com efeito, o perigo real para o agente burguês ocorre quando o grupo intelectual se propõe a incitar e a organizar os amplos setores insatisfeitos com os problemas concretos trazidos pela ordem econômica capitalista. De tal sorte que a diferenciação das hostilidades é de fundamental importância na narrativa e argumentação de Schumpeter. Se o último tipo de hostilidade ao sistema é independente da hostilidade do grupo intelectual, ou seja, a insatisfação com os eventuais e possíveis resultados da ação protagonizada pelo agente econômico capitalista surge da própria dinâmica e processo de desenvolvimento da economia em que ele é o principal ator, a capacidade de organização ideológica e de verbalização lógica e coerente das insatisfações é matéria exclusiva do grupo intelectual.

6 Habermas demonstra muito bem a importância fundamental da opinião pública na formação da sociedade burguesa. E de como essa portava aspectos de consciência crítica sobre os problemas da sociedade nascente. Ver Jürgen Habermas - Mudança Estrutural da Esfera Pública, ed. Tempo Brasileiro. 
Para o economista e cientista social austro-americano, quando os setores que são prejudicados pela evolução e dinâmica da economia moderna de mercado escutam, compreendem e se fascinam pelo intelectual, ele "torna-se quase invariavelmente consciente da existência de um abismo intransponível, se é que não sente uma desconfiança total" (Schumpeter, 1961, p. 192) pela ordem social vigente. É desta forma que o resultado do desmoronamento da armação de aço (a simbiose ativa) e da hostilidade crescente do grupo social dos intelectuais criava as condições e a tendência cada vez mais evidente do sistema capitalista e do agente econômico burguês a entrarem em decomposição (decadência) e, consequentemente, a fornecerem os elementos e condições sociais e políticas para a transição a uma ordem econômica socialista. Diz Schumpeter:

o mesmo processo econômico que solapa a posição da burguesia [...] ao destruir as camadas e instituições protetoras e ao criar uma atmosfera de hostilidade, decompõe também, atuando de dentro, a própria força motriz do capitalismo. Nada mais mostrará tão meridianamente que a ordem capitalista depende não apenas de escoras feitas de material extracapitalista, mas que obtém também sua energia de conjuntos de atitudes extracapitalista que eventualmente destruirá [...] tais fatores contribuem não apenas para a destruição do capitalismo, mas para o surgimento de uma civilização socialista. Todos eles trabalham nessa direção. $\mathrm{O}$ processo capitalista não apenas destrói sua própria moldura institucional, mas cria também as condições para outra (Ibidem, p. 202).

O problema da exposição narrativa de Schumpeter não residia apenas em descrever, por um lado, o esfacelamento da armação de aço que surgiu na aurora da sociedade moderna com a simbiose entre o novo agente social e econômico e os setores políticos remanescentes do mundo feudal que protegiam a ordem capitalista e, por outro lado, a hostilidade crescente ao sistema econômico 
de mercado impulsionado pelo grupo intelectual e àqueles que os ouviam; residia isto sim, e sobretudo, em identificar os mecanismos que ainda possibilitassem à ordem política de sustentação da economia capitalista a sobrevivência. E isto mesmo com todas as tendências de declínio reveladas pela própria narrativa de C.S.D, pois Schumpeter tinha no horizonte a metáfora por ele mesmo construída no início de sua obra: "[os] fatos [são] sombrios [...] [mas] a comunicação de que um navio vai a pique nada tem de derrotista [...] A tripulação pode sentar-se confortavelmente e começar a beber. Mas pode correr também para as bombas" (Ibidem, p. 9). Assim, a posição da Parte IV de C.S.D. no local específico em que se encontra procura responder às questões apresentada pelas outras partes da obra, particularmente a Parte II e os capítulos que expomos há pouco. O quadro descrito por Schumpeter vislumbrava as "possibilidades de socialização" da economia capitalista (Schumpeter, 1961, p. 12), tendo em vista o desmoronamento da armação protetora e a hostilidade crescente dos intelectuais e dos que os ouviam. No entanto, o ponto inicial do processo dado o "método [...] gradual" do fenômeno intrínseco da socialização indicava "nada mais do que uma tendência a longo prazo" (Ibidem). Ainda assim, seria imprescindível entender, precisamente, o sentido e a estratégia de socialização que adviria no decurso do tempo. Vale dizer, para Schumpeter dever-se-ia buscar tal entendimento de sorte a se estabelecer uma "socialização democrática [combinada] com [...] socialismo e democracia" - e o mais importante nos termos de C.S.D. era que a condição para isso tinha de ser a compatibilidade política entre "socialismo e democracia", mas desde "que a última seja definida da maneira proposta no Capítulo XXII do presente trabalho [ ele refere-se a C.S.D.] [e definida como] o princípio de que governos devem surgir da luta competitiva pelo voto" (Ibidem, p. 13).

Pode-se dizer, portanto, que o que está subjacente às construções narrativas de Schumpeter nos textos que analisamos acima é uma 
profunda dimensão normativa ${ }^{7}$ (Held, 1987, p. 150). Deste modo, a articulação das descrições apresentadas pelo economista austro-americano objetivava demonstrar que o sistema capitalista e o agente econômico burguês, se quisessem preservar a ordem política e social que correspondia a seus interesses, deveriam transferir a organização e administração do governo para um grupo social e político não-burguês ("extracapitalista") com a mesma capacidade de ação dos setores pertencentes ao grupo feudal. Era necessária, por um lado, a presença de um grupo social com possibilidades de intervenção no incerto jogo político-institucional similar ao dos setores feudais que formavam a simbiose ativa de proteção à ordem econômica vigente daquele momento; e, por outro lado, de um conjunto de indivíduos com a mesma disposição moral de influência que os intelectuais humanistas hostis à economia de mercado - mas aqui com atitudes integrativas e adaptadas ao ordenamento capitalista enquanto tal. Ocorridas as diversas transformações na sociedade moderna, qual grupo político e social reuniria as condições normativas exigidas pela descrição narrativa de Schumpeter? Esse grupo era a social-democracia europeia. Ainda que sua convivência com os social-democratas tenha sido tensa e conflituosa no contexto de sua participação política efetiva na Comissão para Socialização da República Alemã e do Ministério das Finanças do governo socialista na Áustria, a experiência levou nosso autor a ter a percepção concreta do significado de tal agrupamento político e social, não somente como representante dos interesses do movimento dos trabalhadores, mas na estruturação dos aspectos de conformação, organização e administração de governos nas democracias ocidentais. Antes de analisarmos detidamente a Parte IV de C.S.D., em especial seu último capítulo (cap. 23), que é o local em que Schumpeter desenvolve suas assunções normativas sobre a relação entre o método democrático-institucional de seleção de governantes e a social-democracia, precisamos verificar

A tendência normativo-prescritiva da teoria democrática de Schumpeter são bastante evidentes se tomarmos C.S.D. globalmente. Algo que os leitores de Schumpeter passam despercebido ao atribuírem a ele uma noção exclusivamente descritiva, e por vezes realista, da democracia. 
qual o núcleo constitutivo da experiência histórica schumpeteriana com os partidos políticos e o movimento social-democrata. Para isso, metodologicamente, convém descrever alguns elementos de tal experiência social-democrata no momento na qual Schumpeter estava redigindo C.S.D., pois nosso autor não só conviveu politicamente com tais movimentos, como demonstramos no início, como a estudou, compreendeu e viu de perto na Alemanha, Áustria e em outros países europeus onde o fenômeno se repetiu.

\section{Social-Democracia e o Governo Democrático}

Como afirma Seymour Martin Lipset (1993, p. 46), o autor de C.S.D. "não acreditava que a vitória do socialismo inevitavelmente levaria ao fim da democracia" e, por conseguinte, do sistema econômico capitalista diretamente. E mais: acreditava que os socialistas chegariam ao "poder por meio de eleições" (Ibidem). Este entendimento de Schumpeter havia sido moldado pela própria trajetória histórica e política do movimento socialista, fundamentalmente, os grupos e partidos social-democratas. O partido que historicamente foi criado por Ferdinand Lassalle (no tempo em que Marx ainda era vivo), com o passar dos anos cada vez mais sedimentava em seus princípios e na atuação prática a decisão de participar e integrar a competição eleitoral, e as implicações sociais e econômicas que daí adviriam. Se, ao longo do século XX, a social-democracia iria demonstrar sua capacidade institucional e organizacional de estruturar equilíbrios dado seu comportamento político em seguir as regras procedimentais (Medearis, 2001, pp. 178 e 179) da democracia eleitoral, as bases dessa estratégia foram lançadas na formação do movimento - ainda no século XIX e inícios do XX. Lassalle, um dos formuladores e arquiteto do Programa de Gotha, acreditava que a democracia seria fundamental e imprescindível para se alcançar o socialismo e, a partir de certo momento na Alemanha, ele empreendeu esforços democráticos de diálogo para apoiar os planos de Bismarck (Schorske, 1983, p. 2) concernentes aos problemas políticos e sociais dos trabalhadores. Juntamente com as questões práticas e imediatas lançadas pelos lassalianos, 
Schumpeter acompanhou a construção da teoria social que iria sustentar em boa medida as concepções do movimento social-democrata. Influenciado pelos socialistas fabianos ingleses - que conheceu quando esteve exilado em Londres -, Eduard Bernstein foi um dos primeiros socialistas a criticar as formulações econômicas e políticas de Marx. A consideração de Carl Schorske está correta ao dizer que a teoria de Bernstein chegava "à conclusão que o marxismo [...] já não estava adequado para os fatos da história contemporânea" (1983, p. 16). Da gênese histórica e política com Lassalle e da nova teoria social de Bernstein, os fatos sucessivos no percurso da social-democracia foram de cada vez mais se integrar ao processo eleitoral, visando alcançar o poder "legitimamente pelo voto" (Przerworski, 1991, p. 22). Quais foram as consequências disto? O que tal fenômeno implicou de modo a permitir Schumpeter pressupor e acreditar que, para a operatividade do método institucional de seleção de líderes pelo voto do povo, haveria a necessidade de integração equilibrada e aceitação política da social-democracia a tal arranjo e procedimento?

A primeira e mais óbvia consequência foram os desdobramentos desses dois elementos básicos (gênese histórica e teoria social) na configuração interna e organizativa dos partidos social-democratas. A segunda consequência que Schumpeter pode perceber havia sido a participação da social-democracia na revolução alemã de 1918 e no governo socialista na Áustria. E a terceira consequência foi o modo como os social-democratas atuaram na construção da Constituição de Weimar e no debate teórico específico acerca do desenvolvimento econômico capitalista ocorrido na Áustria entre os austro-marxistas. Segue, então, que com a evolução de setores fundamentais da indústria alemã no final do século XIX formou-se rapidamente uma classe trabalhadora avançada e que teve grande efeito na estruturação da sociedade na Alemanha daquele momento. Com a clara compreensão de que a luta por melhores condições de vida - trabalho, salário, segurança na fábrica - era um direito de todo trabalhador, os operários alemães organizaram os primeiros sindicatos em 1860. Mas foi somente em 1890 que eles se tornaram 
"importantes no desenvolvimento da social-democracia" (Schorske, 1983 , p. 9). Muito embora não fossem todos os sindicatos que aderiram ao partido (e ao movimento) social-democrata, houve neste contexto político e social alemão certa convergência de interesses e estratégia. É certo que no princípio os social-democratas professavam ideias socialistas, enquanto os sindicatos "enfatizavam somente a perseguição dos interesses materiais dos trabalhadores" (Ibidem, p. 12) de maneira mais imediata e cotidiana; porém, muito em breve Carl Legien afirmaria que "os membros dos sindicatos alemães são a maior parte do partido social-democrata" (Ibidem, p. 13). Assim, o agrupamento que iria na teoria democrática de Schumpeter sustentar a competição eleitoral dos líderes políticos teve de se defrontar com o modelo político de atuação das trade-unions. Ora, uma massa de interesses imediatos na mecânica interna dos partidos social-democratas fez surgir em seu seio a autoridade burocrática. Aqui, precisamente, houve uma sobreposição de burocracia sindical com a estrutura burocrática do partido. Estruturados para a estratégia fortemente centralizada de negociações, bem como para a administração dos escritórios, os sindicatos alemães basearam suas atividades no rígido controle político e institucional da ação de seus trabalhadores e membros: de modo que eles, portanto, "dependiam para [...] sucesso da organização do número máximo de trabalhadores [sindicalizados]" (Ibidem, p. 11). E, conquanto, o partido tinha entre seus membros, jornalistas, economistas, professores universitários, políticos vocacionados para o parlamento e operários intelectualizados, a "burocracia [tinha] sido desde há muito, singularmente [sua] principal característica” (Ibidem, p. 16). $\mathrm{O}$ aspecto conservador da social-democracia, assim, está associado ao processo de burocratização porque passa, tendo em vista o jogo democrático-eleitoral e a teorização de que o capitalismo tinha chegado a estágios consideráveis de estabilidade social e que a revolução, portanto, não era necessária e nem desejável. $\mathrm{E}$, na medida em que esta articulação foi se consolidando na maneira de proceder estratégica e tática da social-democracia, as tendências e dinâmicas burocráticas do partido tornavam-se mais oligarquizadas. 
O controle da organização que se projetava prioritariamente para o jogo eleitoral e a política de coalizões no parlamento, conjugada com a recusa em agir espontânea e insurrecionalmente, o que colocaria a estabilidade sob suspeição, proporcionava aos principais líderes do partido um poder crescentemente oligárquico sobre a estrutura organizativa. Com efeito, a conformação de tal agrupamento político que possui influência decisiva em setores materialmente hostis à economia capitalista seria fundamental na restauração da armação protetora que Schumpeter iria propor com a criação do método institucional de seleção de governantes pelo voto do povo. O teste histórico chegaria com a Revolução Alemã de 1918 e a proclamação da República de Weimar em 1919. Algumas breves palavras sobre esses dois acontecimentos e sobre a experiência teórica da social-democracia austríaca podem ilustrar nossas formulações e argumentos mais específicos.

Naturalmente, a compreensão da social-democracia como imprescindível para a operatividade do método institucional de seleção de governantes que competem pelo voto do povo erigido por Joseph Schumpeter exigiria uma descrição empírica mais acurada a partir de experiências de governo que se sucederam ao longo do século XX. Mas se, por um lado, as limitações formais do presente artigo não o permitem, por outro, a própria trajetória pessoal, intelectual e política de Schumpeter nos dispensa de abordagem mais acuradamente histórico-empírica. É que C.S.D. foi planejado e redigido nas primeiras décadas do século passado, sendo terminado em 1942. O próprio Schumpeter viveria apenas mais oito anos, falecendo em 1950 nos Estados Unidos. Ou seja, o economista e cientista social austro-americano presenciou efetivamente a experimentação social-democrata que estamos apresentando ao leitor brevemente. Ora, tais circunstâncias foram suficientes para nosso autor e sua teoria democrática explicitar as possibilidades de reconstrução estável da armação de aço que uma vez na história havia protegido o agente econômico burguês e o capitalismo e novamente poderia, no século XX, exercer a mesma função política. Historicamente, desde seu início com Lassalle, o movimento social-democrata alemão (e 
posteriormente austríaco, claro que com diferenças importantes que não poderemos explicitar aqui dado nossos objetivos e hipótese de trabalho), em sua estratégia política, buscou o regime democrático, de sorte que por ele se chegaria ao socialismo. A revolução de 1918 na Alemanha e o governo austríaco do mesmo período exemplificaram as ações que os social-democratas tiveram diante da realidade defrontada por eles. Já antes da revolução de 1918-1919 a "direção do SPD, liderada do Ebert e Scheidemann, em nome da disciplina partidária, expulsa a oposição em bloco e sem discussão" (Loureiro, 2005 , p. 44). O USPD, que ficaria conhecido como os independentes se opuseram ao $S P D$, agora nomeados como os majoritários, fundamentalmente, por eles no momento mais crucial da política alemã no início do século XX terem abandonado "a tática da luta de classes perante o governo e os partidos burgueses [...] e [por terem] apoiado uma guerra sangrenta"8 (Loureiro, 2005, p. 44). As consequências dessa postura foram percebidas em breve - a greve de 28 de janeiro que irrompeu em Berlim resultou na criação de um comitê de delegados com "11 membros" (Ibidem, p. 50), sendo três deles os social-democratas Ebert, Scheidemann e Braun. Desde o início estes majoritários com "Ebert à frente, entram no movimento com objetivo declarado de controlá-lo" (Ibidem). Certos de que a revolução e seus radicais atores eram prejudiciais para se alcançarem consensos institucionais e arranjos políticos moderados (as conhecidas coalizões parlamentares de governo), os social-democratas estavam convencidos de que o "sistema parlamentar" (Ibidem, p. 55) tinha de ser atingido. Era, justamente, por isso que "as massas na rua" foram motivo de "grande preocupação dos líderes do SPD, e de Ebert em particular" (Ibidem). Ao SPD como "figura dominante [...] do governo" (Ibidem) caberia a responsabilidade política e social de organizar e conduzir o "movimento revolucionário para

8 Não é demais lembrar que a social-democracia votou os créditos de guerra em agosto de 1914 no Reichstag. E após isto ainda aprovou um suplemento a este crédito.

9 Estes políticos faziam parte do grupo mais moderado, conservador pode-se dizer, do partido social-democrata alemão. Que possuía outros dois grupos: os independentes em que a principal figura era Kautski e o espartaquistas de Rosa Luxemburgo e Karl Liebknecht. 
o interior do caminho legal, parlamentar e institucional: Ebert procurou "levá-lo das ruas às urnas" (Ibidem).

Dessa forma, os social-democratas, mesmo se defrontando com o contexto político insurrecional de 1918-1919, planejavam como desfecho de seus princípios (e estratégia) "uma coalizão [parlamentar] com os partidos [...] burgueses" (Ibidem, p. 58). Já no governo, o partido de Ebert, Scheidemann e Braun procuraram seguir o "império da lei" e todas as "reivindicações [mais] democráticas" exigidas pelos setores e grupos populares (trabalhadores, camponeses, baixo funcionalismo público e soldados), tais como a "democratização do Exército, da administração e da economia" foram deixadas nas gavetas (Ibidem, pp. 61 e 71). Na Constituição de Weimar, Schumpeter que não era só, já naquele momento, um dos grandes, senão o maior teórico da economia na Europa, mas um atento e preocupado analista das conjunturas políticas daquele momento, pode perceber o significado do movimento social-democrata na construção de arranjos político-institucionais. O partido de Ebert, o $S P D$, consolidava sua tendência moderada e de busca por acordos e coalizões com os outros partidos (liberais, conservadores, católicos e protestantes). Com efeito, na Assembleia de Weimar eles se consideravam os portadores "da legalidade" e sempre prontos a "buscar a cooperação com os outros partidos burgueses". O desfecho foi que com "11 membros" participantes na comissão que esboçaria o documento final da Constituição de Weimar, o SPD legitimava um regime político e social assentado nas "formas [...] de um sistema parlamentar-presidencialista” (Rürup, 1992, pp. 131, 146 e 151) na qual a principal intenção era servir de instrumento "para manter o status-quo" (Ibidem, p. 155). Pois as medidas mais importantes para a construção de uma ordem social, econômica e politicamente mais igualitária ficariam na Constituição de Weimar em segundo plano. Assim, Schumpeter pode verificar de sua Áustria, também em período de efervescência, que a "coalizão de Weimar" (Loureiro, 2005, p. 83), uma "coalizão da ordem entre social-democratas e a burguesia" (Rürup, 1968, p. 131), que o partido socialista de Ebert, Scheidemann, Braun e Noske não só compactuava com uma 
constituição forjada para impedir a democratização efetiva (social e econômica), mas como que legitimava um documento legal no qual as "disposições [formais] democráticas [...] não passavam de cláusulas secundárias" (Loureiro, 2005, p. 113) diante da lógica constitutiva do arranjo legal de Weimar.

No contexto político austríaco que é o próprio de Schumpeter, ele encontrará um cenário mais plácido, mas não sem alguma efervescência política e social. O que gostaria de chamar a atenção neste aspecto é, particularmente, quanto ao debate teórico político e teórico econômico que os austro-marxistas, ou a social-democracia austríaca, travaram nestas circunstâncias e que em alguma medida moldou o modo pelo qual Schumpeter compreendeu pontos fundamentais da atitude política dos socialistas de Viena. As figuras mais marcantes e influentes nestes debates presenciados (e com certa participação) por Schumpeter foram Rudolf Hilferding, Otto Bauer e Karl Renner. As questões teóricas e conceituais nas quais concentraram seus esforços diziam respeito à forma do Estado (da democracia) e ao horizonte futuro da economia capitalista. Dados os limites do presente artigo, vejamos mais de perto somente Hilferding. O autor de C.S.D. pode, com efeito, verificar que o princípio norteador das concepções políticas de Hilferding era a "indeterminação [na] definição do Estado como órgão executivo (vollzugsorgan) da sociedade" (Marramao, 1990, p. 164). Ou seja, muito diferente dos socialistas revolucionários para quem o Estado fora interpretado como determinantemente de classe - no contexto de então da classe burguesa -, Hilferding compreendia o Estado a partir de noções irresolutas e, por vezes, vagas acerca do delineamento do Estado como órgão de execução de políticas econômicas. Tal princípio de entendimento dava a Hilferding a possibilidade de refletir sobre o abandono de um "socialismo científico revolucionário e marxista, em favor de [um] socialismo construtivo [...] traduzi[do] na racionalidade da linguagem institucional própria do Estado democrático" (Marramao, 1990, p. 166), na qual os partidos políticos mais importantes acordam com um governo de coalizão. Esta concepção de Estado e de democracia 
assentada na fórmula da indeterminação de classe abria espaço interpretativo para Hilferding introduzir em seu corpus teórico a noção de capitalismo organizado. Ele chegava à conclusão, que de acordo com Michaelides e Millos (2005) influenciaria Schumpeter, de que o processo de desenvolvimento tecnológico com monopolização das grandes indústrias, mesmo que instável e com períodos de crise, poderia ser atenuado, resolvido até, por intermédio da política institucional. Isso sem necessidade de intervir, exogenamente, na "legalidade intrínseca" dos ciclos econômicos - as crises, se porventura viessem, eram resultado da "incapacidade administrativa [e institucional]" (Marramao, 1990, p. 171) das forças sociais mais importantes em lidar com a articulação entre o Estado indeterminado e o capitalismo organizado. Com isto, a política de coalizão parlamentar surgia, para os austro-marxistas ${ }^{10}$, assim como para o partido de Ebert, Scheidemann e Braun, para resolver as principais questões referentes à economia e à política como tal. Foram estas experiências e percepções teóricas que permitiram a brecha para Schumpeter, como "grande especialista" no desenvolvimento capitalista (Idem, 1985, p. 307), ser ministro das finanças do "governo de coalizão" (Ibidem) de Karl Renner. Este panorama histórico e político dos partidos social-democratas na Alemanha e na Áustria foram decisivos na elaboração do método democrático e suas condições operatividade, tal como as apresentam C.S.D. Uma vez mais - essa era a preocupação teórica de Schumpeter ao escrever seu Magnum Opus.

10 Neste aspecto, ainda que com uma postura mais radical que a social-democracia alemã, os austromarxistas, também estavam bastante convencidos das possibilidades oferecidas pela política de coalizão parlamentar, pela política de acordos institucionais (sendo que Karl Renner foi o mais adepto das coalizões e Otto Bauer o mais distante por sua experiência na Rússia de 1917). Ver Norbert Leser - Austro-Marxism: A Reappraisal, Journal of Contemporary History, no 2, v. 1. Sobre Otto Bauer especialmente, ver Giacomo Marramao, op. cit. 1985. Outro aspecto a ser observado e de interesse neste contexto é que os social-democratas austríacos estavam profundamente influenciados pela inovadora cultura intelectual, artística e educacional vienense de começo do século XX; ao mesmo tempo a preocupação de Bauer e outros membros do seu partido com a questão nacional era mais intensa do que o da social-democracia alemã, dados os problemas do Império Austro-Húngaro. Ver William M. Johnston - The Austrian Mind: Na Intellectual and Social History 1848-1938, ed. University of California Press. 


\section{As Condições de Funcionamento do Método Institucional de Seleção de Governantes}

As experiências histórico-política e histórico-teórica da socialdemocracia alemã e austríaca respectivamente permitiram Schumpeter avançar a seguinte formulação:

Já enfatizei que não se pode esperar que a democracia funcione satisfatoriamente a não ser que a vasta maioria da população em todas as classes esteja resolvida a ater-se às regras do jogo democrático; isso por sua vez, implica que todos estejam substancialmente de acordo quanto ao fundamental de sua estrutura institucional. No presente momento, a última condição não é satisfeita. Tantas pessoas renunciaram e tantas mais vão renunciar a seu compromisso com os padrões da sociedade capitalista que, nesse terreno, a democracia está fadada a funcionar com crescente fricção. Entretanto, ao estágio visualizado, o socialismo pode tapar a brecha. Pode restabelecer a concordância quanto aos princípios estruturais do tecido social. Se o fizer, os antagonismos remanescentes serão exatamente do tipo que o método democrático é perfeitamente capaz de enfrentar (Grifo meu) (Schumpeter, 1984, pp. 374 e 375).

Era esta a condição fundamental para que o "método democrático [...] aquele acordo institucional para se chegar a decisões políticas em que indivíduos adquirem o poder de decisão através de uma luta competitiva pelos votos da população" (Ibidem, p. 336) funcionasse com operatividade satisfatória ao longo do tempo. Reconstruamos a seguir, portanto, os termos do problema que levou C.S.D. a essa argumentação e vejamos em que medida ela sustenta nossa hipótese de trabalho. Nosso foco aqui será o último capítulo da Parte IV - Socialismo e Democracia de C.S.D.; qual seja, o capítulo 23, Inferência.

Uma vez erigido o método procedimental de seleção de governantes, método esse que substitui a doutrina clássica da democracia, 
seu funcionamento eficiente, estável e duradouro exige certas condições. Além da qualidade distintiva dos homens que ocuparão "posições de liderança” (Ibidem, p. 359), algo que é interno ao método democrático enquanto tal, há a necessidade de condições exteriores ao método, e que o protegerão de eventuais ocorrências sociais (e políticas) perturbadoras. São quatro as condições de operatividade estabelecidas por Schumpeter e que somente os movimentos social-democratas conseguiriam ofertar ao método democrático. E notem que as quatro condições estão, organicamente, associadas aos movimentos e partidos social-democratas tal como descrevemos acima e que Schumpeter pode observar, estudar e participar efetivamente. As condições são: primeiro, um material político de alta qualidade; segundo, as decisões efetivas da democracia devem ser limitadas; terceiro, a presença de um corpo burocrático bem capacitado; e quarto, a construção consensual do autocontrole democrático. Com efeito, Schumpeter, muito além do que os leitores e estudiosos de sua teoria democrática elitista asseguram, não estava preocupado somente em demonstrar a inviabilidade prática da doutrina clássica da democracia e ao mesmo tempo em construir um modelo democrático restrito, por consequência, à competição pelo voto do povo no interior das elites políticas; o autor de C.S.D. tinha no seu horizonte teórico o problema de quais eram as exigências políticas e institucionais para que o método democrático operasse e quem seriam os agentes que cumpririam e promoveriam tais exigências. A primeira condição de êxito do método democrático significava escolher entre os grupos que constituem a estrutura social os mais "disponíveis para a vocação política" (Schumpeter, 1984, p. 361). Quer dizer, a possibilidade de eficácia política do método democrático estaria mais próxima de realizar seus objetivos se conseguisse estabelecer um material humano típico para a carreira responsável da política estatal. Ora, Schumpeter procurava neste ponto específico homens que possuíssem aptidão enérgica para conduzir o "sistema político" que circunstancialmente pudesse se defrontar com momentos de perturbação social. Uma vez que a primeira condição estivesse sido estabelecida, a segunda exigência 
para a operatividade do método democrático deveria ser que as decisões dos políticos, daqueles indivíduos de alta vocação, fossem restritas (Ibidem). Diz Schumpeter: "o sucesso da democracia é que o alcance efetivo da decisão política não deve estender-se a muito longe" (Ibidem). Essa formulação particular acerca das condições de êxito do método institucional de seleção de governantes merece atenção especial, dada nossa hipótese de trabalho. Schumpeter não tinha somente se persuadido de que, com o desmoronamento das paredes de proteção, a armação de aço possibilitada pela simbiose ativa do agente econômico burguês e os grupos feudais, combinada com a hostilidade crescente dos intelectuais, poderiam levar a circunstâncias históricas de dissolução e desagregação do mundo moderno da classe burguesa. Mas, além disso, e do mesmo modo que outros teóricos europeus (como Max Weber, Carl Schmitt, Gaetano Mosca e Ortega y Gasset), Schumpeter estava angustiado com o "declínio [...] da democracia representativa" (Scheurman, 2001, p. 244). A fragilidade constitutiva das "instituições parlamentares liberais" (Ibidem), bem como o surgimento dos partidos de massa nos primeiros anos do século XX, trazia para o cenário político do Europa do entre guerras aspectos trágicos. Estes fatores levavam a que os setores da sociedade mais prejudicados pela racionalidade do desenvolvimento capitalista exigissem, efetiva e moralmente, uma maior igualdade política e econômica (Ibidem, p. 245), de modo que suas demandas pudessem ser aprofundadas por toda a estrutura social. Aqui não se deve perder do horizonte que, conquanto tenha participado de governos social-democratas na Alemanha e na Áustria (Comissão Social para Socialização e Ministério das Finanças, respectivamente), Schumpeter possuía uma mentalidade (cultura familiar e hábitos adquiridos socialmente) e professava valores conservadores (Beckrath, 1965, p. 232; Wright, 1965, pp. 276 e 277). E que, portanto, para ele a "democratização" (Scheurman, 2001, p. 245) extensiva e aprofundada "implica[va] [em] caos" (Ibidem). Deste modo, a necessidade de restringir as decisões políticas da democracia (do governo por assim dizer) era condição inarredável para o sucesso do método democrático de 
seleção de líderes. No governo, os homens vocacionados para a vida política da nação devem procurar ao máximo reduzir a quantidade de questões a serem debatidas; e estas, uma vez sendo postas para o debate, o governo e os políticos têm de conduzi-las a decisões puramente formais e "de natureza meramente surpervisora". Schumpeter conclui esse ponto afirmando que: "se assim não for, o método democrático pode produzir aberrações legislativas” (1984, p. 363).

Dissemos que Schumpeter participou e pode verificar a ação dos partidos socialistas na Alemanha e na Áustria e que presenciou seu caráter burocrático e imobilista. Mas também, como todo cientista social germânico de seu tempo, o autor de C.S.D. muito provavelmente conheceu a sociologia política de Robert Michels e a questão da burocracia ali presente como uma das manifestações políticas características da evolução dos partidos social-democratas e da administração pública moderna - e a demonstração de eficiência do corpo burocrático na condução de grandes organizações e das pessoas presentes nestas. Assim, a terceira condição para a operatividade do método democrático de seleção de governantes para Schumpeter tinha de ser a oferta "dos serviços de uma burocracia bem-treinada e de boa posição e tradição, dotada de forte senso de dever e de não menos forte espirit de corps" (Ibidem, p. 365). No horizonte de C.S.D. não estava somente a capacidade da burocracia em administrar o cotidiano do governo no âmbito da "moderna sociedade industrial" (Ibidem); mais preocupado com a conformação do grupo extra-capitalista para substituir os setores feudais e aristocráticos, o que se vislumbrava nos termos do método democrático com o corpo burocrático era a condução "eficiente" e moderada da política. Seu senso de dever público, acompanhado de cultura corporativa e treinamento técnico-racional, forjava na burocracia certos "código[s] tradiciona[is]" (Ibidem) de serenidade na atitude política e autocontenção no trato das questões envolvendo decisões de Estado.

A quarta condição para o funcionamento eficaz do método institucional de seleção de governantes é o que Schumpeter nomeou de "autocontrole democrático" (Ibidem, p. 366). Diz ele: 
Autocontrole democrático. Todos, naturalmente, concordarão em que o método democrático não pode funcionar adequadamente a não ser que todos os grupos importantes de uma nação ${ }^{11}$ estejam dispostos a aceitar qualquer medida legislativa, desde que esteja no livro dos estatutos e que todas as ordens executivas emanem das autoridades legalmente competentes (Grifo meu) (Schumpeter, 1984, p. 366).

Não seria exagero de nossa parte afirmar que esta exigência é a mais fundamental no contexto de construção da teoria democrática de Schumpeter assentada no método institucional de seleção de governantes. Enquanto tal, a própria configuração do método democrático erigido por C.S.D. de certo modo estabeleceria mecanismos de restrição da ação efetiva do governo e dos grupos que momentaneamente estivessem na oposição - a estrutura procedimental, de fato, foi pensada para isso (Bachrach, 1973). Mas Schumpeter preocupava-se com os grupos sociais como agentes ativos e dinâmicos no jogo político das nações. Com a fragilidade institucional da ordem burguesa após o desaparecimento da armação protetora propiciada pelos setores feudais (simbiose ativa), e a tendência de enfraquecimento dos arranjos econômicos capitalistas, o método democrático para sua operatividade eficaz e, relativamente, estável deveria envolver "um bocado de subordinação voluntária” (Schumpeter, 1984, p. 366). Quer dizer, o método democrático schumpeteriano de democracia não comporta ofertas políticas que apressem, radicalmente, a ordem legislativa, constitucional e institucional. Com efeito, "as propostas individuais [...] legislativa[s] ou [...] a ação executiva devem, por assim dizer, contentar-se em se colocar numa fila ordeira de racionamento;

11 A compreensão de Schumpeter sobre a função de proteção ao método democrático que a socialdemocracia poderia dispor está em acordo com os aspectos de defesa da nação por sobre as classes que caracterizou muita das ações políticas dos social-democratas no entre guerras. A aprovação dos créditos de guerra em 1914 pelo partido de Ebert, Noske e Scheidemann e de certas postulações nacionalistas de Bernstein e Otto Bauer respondem àquele princípio de defesa dos interesses da nação, de modo que a concordância dos grupos sociais mais importantes era fundamental para a realização destes interesses. 
não devem tentar apressar a loja" (Ibidem). O funcionamento do método democrático, portanto, exigia que a "guerra política" fosse travada no âmbito de certas normas procedimentais: graus significativos de sobriedade "e tradicionalismo" institucional (Ibidem) são requisitos insubstituíveis no esquema teórico de Schumpeter. Ainda assim, havia outro aspecto do autocontrole democrático que se constituía como imprescindível para a operatividade do método democrático. C.S.D. foi escrito num momento histórico na qual os "tempos [eram] conturbados" (Ibidem, p. 368), de tal modo que toda ordem moral, social e econômica da Europa e em outras partes do mundo (Estados Unidos, por exemplo) estava sendo contestada. Dessa forma, a seleção de governantes por competição pelo voto do povo seria insuficiente, o que colocaria a própria democracia em risco, na ocorrência constante de "práticas desviantes" (Ibidem), mesmo estas sendo limitadas às regras estabelecidas pelas instituições e autoridade dos líderes. Assim, o risco era real, de sorte que se "interesses importantes" outros (dos grupos e movimentos oposicionistas) não chegassem a atitudes quase "unânimes" e aderissem "aos princípios estruturais da sociedade existente" (Schumpeter, 1984, p 368), o método democrático estaria ameaçado. Pois,

sempre que esses princípios forem postos em questão e que surjam temas que coloquem a nação em dois campos hostis, a democracia funcionará com desvantagens. E pode deixar de funcionar completamente se o caso envolver interesses e ideias a respeito dos quais as pessoas se recusam a se comprometer. Isso pode ser generalizado de maneira [a fazer] que o método democrático [fique] em desvantagem em tempos conturbados (Ibidem).

A implicação teórica geral das condições impreteríveis de funcionamento do método democrático é que ele não estenderia "a esfera política, a todos os negócios econômicos” (Ibidem, p. 372). Se, por um lado, a história social e econômica do agente burguês demonstrava que ele, de fato, adaptar-se-ia harmonicamente ao método 
democrático, ou seja, à constituição de uma esfera política que, fundada nas exigências de autocontenção, não só evita estender-se aos negócios econômicos, mas a protegê-los como uma armação (de aço) protetora, tal como Schumpeter projetou; por outro lado, ficava por ser evidenciado em que medida o socialismo teria, voluntariamente, compreendido o significado teórico e prático do método democrático e suas implicações acima expostas - e se condicionaria e ele. De modo que esta seria a possibilidade substantiva para a operatividade do próprio método democrático-institucional de seleção de governantes. Uma vez isto sendo alcançado, a reconstrução das paredes que protegem a ordem econômica capitalista estaria garantida. Assim, o pressuposto de C.S.D. era que, mesmo havendo tipos de socialismo histórica e politicamente infensos ao método democrático, ainda assim e tal como expusemos no ponto anterior, havia socialismos, os movimentos social-democratas, que Schumpeter conheceu, estudou e tomou contato que eram "potencialmente tratáve[is]" (Medearis, 1997, p. 828). E que estavam "convencidos [...] e de acordo" (Wright,1951, p. 154) de que o método democrático, "a competição [pelas elites] para a difícil tarefa de administrar o sistema" (Ibidem) era a melhor maneira de convivência política. Schumpeter termina essa parte de C.S.D. demonstrando a validade de seus pressupostos narrando a seguinte experiência; diz ele:

os socialistas sérios, quando fora do palanque e num espírito responsável, sempre têm consciência [de certos] problema[s] [...] Podemos oferecer uma ilustração interessante [...] da Comissão Alemã sobre Socialização (Sozialisierungs Kommission). Em 1919 [...] o Partido Social Democrata alemão [e alguns] dos mais radicais de seus membros ainda acreditavam em alguma medida de socialização [...] Karl Kautski era o presidente. E ele só fez recomendações definidas a respeito do carvão, e mesmo essas [...] carregadas [com] nuvens do sentimento anti-socialista [...] Interessantes são os pontos de vista que emergiram na discussão à época [...] $A$ 
ideia de os administradores das fabricas serem eleitos pelos trabalhadores [...] era franca e unanimemente condenada. Os conselhos de trabalhadores que cresciam nos meses de colapso universal era objeto de desagrado e suspeita pelos [social-democratas] (Grifo meu) (Schumpeter, 1984, p. 373).

Nosso autor estava convencido de que os socialistas, os partidos e movimentos social-democratas, tornando operativo e, eficazmente funcional, o método democrático, poderiam "tapar a brecha" deixada pelos grupos feudais (extra-capitalistas) e sua armação protetora e com isso não deixar o "navio [ir] a pique".

\section{Conclusão}

O presente artigo teve como objetivo defender a hipótese de trabalho de que, mais do que desaprovar a doutrina clássica da democracia e erigir em substituição a ela "uma outra teoria da democracia" a partir do método institucional de seleção de governantes pelo voto do povo (para tomarem decisões políticas), Joseph Schumpeter construiu sua teoria democrática tendo como núcleo constitutivo a operatividade estável, equilibrada e autocontida do método democrático e que, para isso, havia a necessidade fundamental da presença em tal arranjo político dos partidos socialistas precisamente, os partidos e movimentos social-democratas. Mesmo que C.S.D. seja entendido, desde sua publicação em 1942, como um dos textos, o principal talvez, de inauguração da democracia elitista e que se atribua a Schumpeter a teorização inicial que argumenta que democracia é antes de tudo um método procedimental para escolha de líderes políticos, e consequentemente para a formação do governo, é plausível a hipótese que aqui neste artigo defendemos tendo em vista a leitura ao mesmo tempo mais global (prefácios, Parte II) e específica (capítulo 23 da Parte IV, Inferência) de Capitalismo, Socialismo e Democracia. Três considerações podem ser feitas a partir de nossa argumentação. Primeiro, que Schumpeter, como expressão consciente da cultura intelectual e política europeia do entre guerras, compreendeu o caráter instável, e, por vezes, frágil 
da democracia (e da sociedade capitalista) no contexto de grandes e intensas transformações da ordem social, econômica e moral da era moderna - isto pode acurar nossas percepções acerca dos problemas enfrentados pelos regimes democráticos na contemporaneidade e seus constantes problemas de transformação das estruturas societárias. Segundo, fica a noção de que a concordância dos principais grupos políticos da sociedade industrial, e/ou pós-industrial, é decisiva para que a ordem democrática, tal como Schumpeter e seu conservadorismo entendeu essa, funcione de maneira estável, equilibrada e autocontida. Terceiro, pode-se estabelecer a partir de certos aspectos da argumentação que apresentamos a formulação de hipótese de trabalho interpretativa sobre pontos específicos da crise de instabilidade e legitimidade das democracias contemporâneas, pois na medida em que foi cada vez mais se tornando adepta do método democrático, das normas procedimentais de governo e respondendo a situações políticas e sociais imprescindíveis para o funcionamento equilibrado da democracia apenas em circunstâncias de competição pelo voto do povo, a social-democracia se afastou de seu caráter extra-capitalista, tornando o sistema político como tal não representável para o conjunto da sociedade, sobretudo para os grupos sociais mais populares em sentido amplo ${ }^{12}$ (trabalhadores, baixo funcionalismo público, setores rurais, trabalhadores dos serviços). O modelo schumpeteriano, uma vez construído, pressupõe para seu funcionamento do jogo a concordância e subordinação voluntária ao método democrático (às regras procedimentais de seleção de governantes) com a presença de agentes extra-capitalistas. Cabe testar o modelo, mas isso em outro artigo e para pesquisadores de outras áreas da ciência política mais capacitados para tal.

12 Para complementar esta postulação, ver de maneira articulada os seguintes trabalhos: Perry Anderson - Introdução In: Um Mapa da Esquerda na Europa Ocidental, Perry Anderson e Patrick Camiller (Org.), ed. Contraponto, 1996; Peter Mair - Os Partidos Políticos e a Democracia. Revista Análise Social, no 167, v. xxxviii, 2003; e Adam Przerworski - Democracy and the Limits of Self-Government, ed. Cambridge University Press, 2010, em especial o capítulo 5). 


\section{Bibliografia}

ALLEN, Robert Loring. (1991) Opening doors: the life \& work of Joseph Schumpeter, New Jersey: Transaction Publishers.

ANDERSEN, Esben Sloth. (2006) Schumpeter's general theory of social evolution: the early version. Paper for the Conference on Neo-Schumpeterian Economics: An Agenda for the 21 $1^{\text {st }}$ Century. ANDERSON, Perry. (1996) Introdução. In: ANDERSON, Perry e CAMILLER, Patrick (Org.). Um mapa da esquerda na europa ocidental, Rio de Janeiro: Contraponto.

BACHRACH, Peter. (1973) Critica de la teoria elitista de la democracia. Bueno Aires: Amorrortu.

BECKRATH, Herbert von. (1965) Joseph A. Schumpeter como sociólogo. In: HARRIS, Seymour E. (Ed.) Schumpeter, cientifico social (El sistema schumpeteriano), Barcelona: Ediciones de Ocidente.

EBNER, Alexander. (2000) Schumpeter and the 'schmollerprogram': integrating theory and history in the analysis of economics development. Journal Evolutionary Economics, no 10, p. 355-372.

GAMA NETO, Ricardo Borges. (2011) Minimalismo schumpeteriano, teoria econômica da democracia e escolha racional. Revista de Sociologia e Política, no 38, v. 19, p. 27-42.

HELD, David. (1987) Modelos de democracia. Belo Horizonte: Paideia.

HUNTINGTON, Samuel. (1994) A terceira onda de democratização: A democratização no final do século XX, São Paulo: Ática.

JOHNSTON, William M. (1972) The Austrian Mind: an intellectual and social history 1848-1938, Berkeley-Los Angeles-London: University California Press.

LESER, Norbert. (1966) Austro-Marxism: a reappraisal. Journal of Contemporary History, $\mathrm{n}^{\circ}$ 2, v. 1, p. 117-133.

LIPSET, Seymour Martin. (1993) Reflections on capitalism, socialism \& democracy. Journal of Democracy, no 2, v. 4, p.43-54. LOUREIRO, Isabel. (2005) A Revolução Alemã [1918-1923], São Paulo: Unesp. 
MAIR, Peter. (2003) Os partidos políticos e a democracia. Revista Análise Social, no 167 , v. Xxxviii, p. 277-293.

MÄRZ, Eduard. (1991) Joseph Schumpeter: scholar, teacher \& politician, New Haven: Yale University.

MARRAMAO. Giacomo. (1985) Entre bolchevismo e socialdemocracia: Otto Bauer e a cultura política do austromarxismo. In: HOBSBAWM, Eric (Ed.) História do marxismo v. 5. Rio de Janeiro: Paz e Terra.

(1990) O Político e as transformações: crítica do capitalismo e ideologias da crise ente os anos vinte e trinta. Belo Horizonte: Oficina de Livros.

MATTL, Siegfried. (2013) O caso da Viena vermelha. Lua Nova, ${ }^{\circ}$ 89, p. 191-213.

MEDEARIS, John. (1997) Schumpeter, the new deal, and democracy. The American Political Science Review, no 4, v. 91, p. 819-832. (2001) Joseph Schumpeter's two theories of democracy. Cambridge-Massachusetts: Harvard University Press.

MICHAELIDES, Panayots and Milios, John. (2005) Did Hilferding influence Schumpeter? History of Economics Review, v. 41, p. 98-125.

MIGUEL, Luiz Felipe. (2002) A democracia domesticada: bases antidemocráticas do pensamento democrático contemporâneo. Dados, no 3, v.45, p.483-511.

PRISCHING, Manfred. (1989) Evolution and Design of Social Institutions in Austrian Theory. Journal of Economic Studies, $\mathrm{n}^{\circ}$ 2, v. 16, p. 47-62.

PRZERWORSKI, Adam. (1991) Capitalismo e social-democracia. São Paulo: Companhia das Letras.

(2010) Democracy and the limits of self government. New York: Harvard University Press.

RICCI, David. (1970) Democracy attenuated: Schumpeter, the process theory, and american democratic thought. The Journal of Politics, no 2, v. 32, p. 239-267. 
RÜRUP, Reinhard. (1992) Génesis y fundamentos de la constitución de Weimar. In: CARRERAS ARES, Juan José (Ed.) El Estado alemán (1870-1992). Madrid: Marcial Pons.

(1968) Problems of the German Revolution 1918-19. Journal of Contemporary History, no 4, v. 3, p. 109-135. SCHEUERMAN, William. (2001) Carl Schmitt: uma fuente desconocida em la teoria elitista de la democracia de Joseph Schumpeter. In: Medina, Graciela y Mallorquín, Carlos (Coord.) Hacia Carl Schmitt: irresuelto. Puebla/México: Benemérita Universidad Autônoma de Puebla/Instituto de Ciências Sociales y Humanidades.

SCHORSKE, Carl. (1983) German social democracy 1905-1917. The development of the great schism. Cambridge-Massachusetts: Harvard University Press.

SCHUMPETER, Joseph Alois. (1961) Capitalismo, socialismo e democracia. Rio de Janeiro: Fundo de Cultura.

democracia. Rio de Janeiro: Zahar.

SWEDBERG, Richard. (1990) The new 'battles of methods'. Challenge, $\mathrm{n}^{\circ} 1$, v. 33, p. 33-38.

(1991) Schumpeter: a biography. New

Jersey: Princenton University Press.

STOLPER, Wolfgang F. (1994) Joseph Alois Schumpeter: the public life of a private man. New Jersey: Princenton University Press. WITT, Ulrich. (2002) How evolutionary is Schumpeter's theory of economic development? Industry and Innovation, $\mathrm{n}^{\circ} 1 / 2$, v. 9, p. 7-22.

WRIGHT, David McCord. (1951) Schumpeter's political philosophy. The Review of Economics and Statistics, n ${ }^{\circ}$, v. 33, p. 152-157.

\section{Resumo}

O artigo defende a hipótese de que Joseph Schumpeter em Capitalismo, Socialismo e Democracia, mais do que construir uma teoria elitista e procedimental da democracia assentada no método institucional de seleção de governantes que competem pelo voto popular, estava de fato 
profundamente preocupado com a operatividade estável e equilibrado do método uma vez erigido. Pensando nisso Schumpeter passou a sustentar que os partidos socialistas teriam não só papel fundamental na estruturação e condições de funcionamento do método democrático, mas que seriam imprescindíveis para permanência desse e consequentemente da democracia.

Palavras-chaves: Schumpeter; Social-democracia; Operatividade; Método democrático.

\section{Abstract}

The article defends the hypothesis that Joseph Schumpeter in Capitalism, Socialism and Democracy, rather than constructing an elitist and procedural theory of democracy based on the institutional method of selecting rulers competing for popular vote, was in fact deeply concerned with the operability stable and poised of method once erected. With this in mind, Schumpeter went on to argue that the socialist parties would not only have a fundamental role in the structuring and working conditions of the democratic method, but would be essentials for its permanence and consequently for democracy.

Keywords: Schumpeter; Social-democracy; Operability; Democratic method.

Recebido em: 18 de julho de 2018

Aprovado em: 20 de dezembro de 2018 